\title{
Causality among Exports decomposition and economic Growth in case of two BCIM countries
}

\author{
Yang Xin , Md. Mostafizur Rahman, Yinning He \\ School of Economics, Yunnan University of Finance and Economics, \\ Kunming-650221, P.R. China \\ E-mail: simba1219@hotmail.com
}

Department of Statistics, Statistics and Mathematics School, Yunnan University of Finance and Economics, Kunming-650221, P.R. China.

E-mail: mostafiz bd21@yahoo.com

School of Economics , Yunnan University of Finance and Economics,

Kunming-650221, P.R. China

E-mail: 639814690@qq.com

Keywards: Export decomposition, tourism receipt, remittance, BCIM countries, Granger causality test. Abstract : This paper empirically investigated the causal relationship between export decompositions and Economic growth for two BCIM countries mainly China and India. In this paper first we present the upgrading form for export decomposition by adding remittance as an extra factor and then we find out the causality among these variable. Using the time series data for the period 1980-2011 our empirical study showed that in the long run traditional export, tourism and remittance have significant positive effect on the GDP of China and traditional export and remittance have positive significant effect on the GDP of India whereas tourism has positive effect but which is statistically insignificant. Secondly, we find out the causal relationship among these variables by Var Granger Causality test. From the empirical study we found the evidence for unidirectional causality from traditional export to GDP in case of China and from remittance to GDP and traditional export in case of India. Therefore, government should focus on economic policies to promote international tourism and encourages people to go to abroad more.

\section{Introduction}

Economic growth theory based on the aggregate production function is one of the major theories of Macro-economics. The effects of exports on the economic growth are widely accepted for many countries. Exports positively influence the economic growth by relieving foreign exchange (McKinnon 1964) or by enhancing efficiency through increased competition (Krueger 1980). There are many sources of exports and recently researchers pay attention to investigate the actual effect of different sources of exports on the economic growth for a particular country. As for example, Fosu (1990) and Herzer et al (2006) consider primary goods and manufactured goods export. Greenaway et al (1999) divide exports into fuels, food, metals and other primary goods, machinery, textiles and other manufactured goods. Crespo-Cuaresma and Worz (2003) decompose the export into 33 different groups. Balaguer and Cantavella-Jorda (2004) consider food and agricultural goods, primary goods and manufactured goods. Durbarry (2004) distinguish export into sugar, manufactured exports and tourism. Cortés-Jiménez et al (2009) empirically investigated the relationship among exports of goods, inbound tourism and economic growth in case of Italy and Spain. 
Originating in 1999 as the Kunming Initiative, for expanding and investment under the ambit of subregional co-operation comprising four contiguous countries of Eastern South Asia which includes two fast growing economics India and China and two developing economics Bangladesh and Myanmar formed BCIM. There is optimism about the prospects of the initiative in promoting regional cooperation between the geographically contiguous BCIM countries. The region is not only geographically contiguous but also complementary in economic terms. Among the BCIM countries China and India are the two big countries with huge population and their economic development also noticeable. In the ranking of the largest economies of the world measured by their gross domestic products in terms of 1995 constant US\$, China and India stood at the $19^{\text {th }}$ and $20^{\text {th }}$ positions in 1980 , but in 2005 the ranking places them at the $7^{\text {th }}$ and $12^{\text {th }}$ positions, respectively. Such a quantum jump of these two economies, particularly China, over two and a half decades is remarkable. Recently China became the world's second largest economy and India also performing well. The historical data shows that export is important factor for boosting the economy for both countries.

The expansion of China's participation in international trade has been one of the most outstanding features of the country's economic development. Chinese exports rose on average 5.7 percent in the 1980, 12.4 percent in the 1990, and 20.3 percent between 2000 and 2003. By 2003, China's export growth rate was seven times higher than the export growth rate recorded by the world as a whole (Silva-Ruete 2006). The growth performance of India's exports has been highly encouraging only during certain periods after export promotion became a permanent agenda on the national economic policy. Despite continuous efforts by the Government of India to improve the scope and content of a plethora of measures to promote exports India's exports have failed to take off to a long-term sustained growth (Wadhva 1998). According to International Financial Statistics (1997), for the year 1980-1990, the estimated average annual growth rates of exports for some Asian countries as follows: India:7.7 per cent; world: 6.1 per cent; China: 13.1 per cent; South Korea : 14.0 per cent; Malaysia : 8.6 per cent; Singapore : 10.5 per cent; Thailand: 13.6 per cent. During the year 1960 India's export was larger than China's export but China exceeded Indian export almost double at 1980. Kalirajan and Singh (2008) also showed that India is still lag behind compare to Chinese export performance. From the year 1978 to 2006 China's share in the world export of goods and services jumped by more than five times, from $1.4 \%$ to $7.6 \%$ on the other hand India's share in the world export of goods and services grew up from $0.4 \%$ to $1.2 \%$ (Tong, 2007).

Recently, many developing countries give more attention for developing tourism industry because it is treated as one of the key industry for many countries. According to World tourism Organization (WTO 2004), the number of tourist arrival will be reach over 1.56 billion by the year 2020 and tourist expenditure on goods and services cover $8 \%$ of the world export receipts and 5\% of the world GDP (WTO, 2007). China's tourism industry is one of the fastest growing industry and it's tourism revenue increases from 499.5 billion Yuan to 1160 billion Yuan during the year 2001 to 2008 (www.cnta.gov.cn). And it is growing up day by day. On the other hand, tourism industry is also one of the major industries in case of India. India's richest history and cultural and geographical diversity attract more foreign tourist to visit India. According to the statistics there will be approximately 6.30 million foreign tourists arrives in 2013 which is $8 \%$ higher than the year 2010. So, researchers give more attention for tourism industry. For example

(See Sinclair (1998), Lanza et al (2003), Durbarry (2004), Lee and Chen (2008)). Most of the authors argued that tourism has promotes high economic performance, job creation and generating revenue for the government of particular country. Yang (2006) examined the relationship between domestic tourism consumption and economic growth for China and mentioned that bi-directional causality does not exist between these variables. Wu (2003) confirm that tourism plays significant positive role in economic growth. 
Flows of worker's remittances to developing countries (the portion of migrant's earnings sent back from the country of residence to the country of origin) have made noticeable improvement during the last 30 years. At a 7\% annual growth rate during the last decade, they have gone up from 67.6 billion dollars in 1999 to 93 billion in 2003 and about 100 billion in 2005 (Ruiz and Corrons (2010)). According to Dilip Ratha "In many developing countries, remittances provide a lifeline for the poor", he also added that remittances are "often as essential source of foreign exchange and a stabilizing force for the economy in turbulent times". In fact remittances assist the economic growth throughout the world. The money sent home by the migrants make up second biggest financial inflow to numerous developing countries. India is the largest remittances recipient country in the world, receiving \$69 billion in 2012, the World Bank has said. India topped the list of countries receiving remittances, followed by China ( $\$ 60$ billion), the Philippines ( $\$ 24$ billion), Mexico ( $\$ 23$ billion) and Nigeria and Egypt (\$21 billion each). Other large recipients include Pakistan, Bangladesh, Vietnam, and Lebanon (Times of India, April 20, 2013). So, from the above discussion we can say that tourism revenue and remittance are most important factors for Chiese and Indian economy. Rahman et al (2010) established the causal relationship among export, import, FDI and foreign remittance in case of Maldives.

Inspiring by the work of Cortés-Jiménez et al (2009) we extend our paper to decompose export by remittance as an extra factor besides tourism and traditional export. So, the aim of our paper is two fold, first we disaggregate export as traditional export, tourism receipting and remittance and present development model and secondly, we examine the causal relationship among traditional export, tourism and remittance with economic growth in case of two big BCIM countries such as China and India. The rest of the paper is organized as follows: Section 2 presents the Methodology, Section 3 discusses the Empirical study and finally Section 4 presents the conclusions.

\section{Methodology}

At the methodology section we will discuss the extension form of Cobb-Douglas production function by disaggregating export into traditional exports, international tourism receipt and foreign remittance. Durbarry (2004) decomposed exports into export of goods and tourism exports which was also empirically investigated by Cortés-Jiménez et al (2009). So, in this paper we present extension form of Durbarry (2004) by adding remittance as an extra variable. And then we will discuss stationarity, Cointegration tests, Error correction models and Granger Causality test. These are described below:

\section{Expanded Production function}

The standard Cobb-Douglas production function within neoclassical framework can be written as

$$
Y(t)=Q(t)^{\alpha} H(t)^{1-\alpha} A(t), \quad 0<\alpha<1
$$

where $Y(t)$ is quantity of output, $Q(t)$ is physical capital, $H(t)$ is human capital and $A(t)$ is production technology. Barro and Sala-i-Martin(1995) expanded production function. There are many ways to promote economic growth such as foreign investment, education, R\&D and free trade. Mankiw (2004) considered international trade as a type of technology parameter and it convert non-specialized production into specialized production. In case of demand, an inward trade policy can not influence the domestic economic growth because domestic demand is limited but export can play an important role in case of outward oriented country through the expansion of external demand as a component of the aggregate demand function (Agosin 1999; Boriss and Herzer 2006; Cortés-Jiménez et al 2009). On the other hand export can positively influence the economic growth through different means, such as facilitating the exploitation of economic scale (Helpman and Krugmam 1985) or promoting the diffusion of technical knowledge (Grossman and Helpman 1991). So, Cobb-Douglas production function can be expanded by adding exports and can be presented as 


$$
Y(t)=Q(t)^{\alpha} H(t)^{1-\alpha} E(t)^{\delta} A(t)
$$

Many authors disaggregate exports, for example Fosu (1990) and Herzer et al (2006) consider primary goods and manufactured goods exports, Greenaway et al (1999) divide exports into fuels, food, metals, other primary goods, machinery, textiles and other manufactured goods, Durbarry (2004) disaggregate exports into sugar, manufactured exports and tourism. Rahman (2010) distinguish exports as product service of export and foreign remittance. So, in our study we want to disaggregate exports as export of goods, tourism export and foreign remittance based on Durbarry (2004) and Rahman (2010) and this can be presented as

$$
Y(t)=Q(t)^{\alpha} H(t)^{1-\alpha} E G(t)^{\delta} T E(t)^{\gamma} R E(t)^{\lambda}
$$

The equation can be express as linear logarithmic form by

$$
Y(t)=\mu+\alpha Q(t)+(1-\alpha) H(t)+\delta E G(t)+\gamma T E(t)+\lambda R E(t)+\varepsilon(t)
$$

where $\varepsilon(t)$ is error term with mean 0 and constant variance.

\section{Stationarity}

In order to check the stationarity, we used most commonly uses ADF and PP test. The ADF test is a modification over the DF test and lagged values of the dependent variables are added in estimation of equation of $\mathrm{DF}$ test in the following way

$$
\Delta Z_{t}=\delta+(\rho-1) Z_{t-1}+\lambda T+\gamma \Delta Z_{t-1}+\varepsilon_{1 t}
$$

Since it is widely believed that both DF and ADF test do not consider the cases of heteroscedasticity and non-normality frequently revealed in a raw data of economic time series variables the PP test for unit root has been used in the empirical analysis. Moreover, it has an advantage over ADF test when the concerned time series has serial correlation and there is a structural break. Therefore, the PP test provides robust estimates over DF and ADF tests and is based on the following form of equation

$$
\Delta Z_{t}=\phi+(\rho-1) Z_{t-1}+\lambda(t-T / 2)+\psi \Delta Z_{t-i}+\varepsilon_{2 t}
$$

The appropriate critical values of time $t$ statistics for the null hypothesis of non-stationarity are given by Mackinnon (1991). Here $\Delta$ represent the first difference, $\varepsilon_{1 t}$ and $\varepsilon_{2 t}$ are the respective stationary random error term.

\section{Cointegration tests}

Johansen and Juselius (1990) proposed a procedure to test for cointegration for more than two series. The procedure is based on the likelihood ratio test to determine the number of cointegration vectors in the regression. This technique enables to test for the existence of non-unique cointegration relationships. Two test statistics are suggested to determine the number of cointegration vectors based on likelihood ratio test: these are the Trace test and Maximum eigenvalue test statistics.

The trace test is defined as:

$$
\lambda_{\text {trace }}(r)=-T \sum_{i=r+1}^{n} \log \left(1-\hat{\lambda}_{i}\right)
$$

where $\hat{\lambda}_{i}$ is the estimated values of the characteristics roots (called eigenvalues) obtained from the estimated $\lambda$ matrix and $T$ is the number of usable observations. At the trace tests the hypothesis that there are at most $r$ cointegrating vectors. In this test $\lambda_{\text {trace }}$ equals to zero when all $\lambda_{i}$ are zero. The Maximum eigenvalue test is defined as

$$
\lambda_{\text {max }}(r, r+1)=-T \sum_{i=r+1}^{n} \log \left(1-\hat{\lambda}_{r+1}\right)
$$


At the maximum eigen value test the hypothesis that there are $r$ cointegrating vectors versus the hypothesis that there are $r+1$ cointegrating vectors. This means if the value of characteristic root is close to zero, then the $\lambda_{\max }$ will be small.

\section{Error Correction Models}

Having established the long run equilibrium relationship among these variables, the short run adjustments are estimated using the error correction model. Hendry's $(1979,1995)$ general-to-specific approach has been applied in this case where the model (i.e., ECM) is used in the following form. Here we only present the equation for $\mathrm{G}$.

$\Delta G=\varphi_{10}+\sum_{j=1}^{m 1} \phi_{11} \Delta K_{t-j}+\sum_{i=1}^{m 2} \phi_{12} \Delta H_{t-i}+\sum_{k=1}^{m 3} \phi_{13} \Delta E_{t-k}+\sum_{p=1}^{m 4} \phi_{14} \Delta T_{t-p}+\sum_{q=1}^{m 5} \phi_{15} \Delta R_{t-q}-\theta_{1} \varepsilon_{t-1}+e_{1 t}$

where $\Delta$, represent the difference operator, $\theta$ are the error correction term, $e$ are the random disturbance terms, $\mathrm{m} 1, \mathrm{~m} 2, \mathrm{~m} 3, \mathrm{~m} 4$ and $\mathrm{m} 5$ are the number of lag length determined by the Akaike's information criterion (AIC). According to this approach, two lags of both explanatory and dependent variable and one lag of the residual from the co-integrating regression have been included.

\section{Granger Causality test}

Granger causality distinguishes between unidirectional and bi-directional causality (Granger 1969). Unidirectional causality is said to exist from $X$ to $Y$ if $X$ causes $Y$ but $Y$ does not causes $X$. If neither of them causes the other, then the two time series are statistically independent. If each of the variables causes the other, then a mutual feedback is said to exist between the variables. In order to test for Granger causality, we will estimate a VAR model as follows, where all variables are initially considered symmetrically and endogenously.

$$
\begin{aligned}
& {\left[L X_{t}\right]=\alpha+\beta_{1}\left[L X_{t-1}\right]+\beta_{2}\left[L X_{t-2}\right]+\ldots+\beta_{n}\left[L X_{t-n}\right]+\left[U_{t}\right] ;} \\
& X=\left[\begin{array}{llll}
G & E & T & R
\end{array}\right]^{\prime}
\end{aligned}
$$

Where $t$ is the time subscript, $n$ is the number of lags for the VAR, $\alpha$ is the vector of constant and $\beta_{1}, \beta_{2} \ldots \beta_{n}$ are all parameter matrices and the variables have their usual meaning.

\section{Empirical study}

Annual data of real GDP, real gross fixed capital formation, gross enrollments in secondary level of education taken as a proxy for human capital, Traditional exports, international tourism receipts and foreign remittance are used for empirical analysis for both China and India. The annual data cover the period 1980 to 2011 are collected from the World Economic Indicator and from the key indicator for the Asia and the pacific of Asian Development Bank website and different issue of Statistical year book of China and India. At the data set we found some missing data and these data are generated by means of smooth averaging. All the data are transformed into natural logarithms for obtaining stationarity in variance and non linearity relationship (Chang and Caudill (2005)). After transforming these data we define real GDP as G, real gross fixed capital formation as K, gross enrollment in secondary level as $\mathrm{H}$, traditional export as $\mathrm{E}$, and international tourism receipts as $\mathrm{T}$ and foreign remittance as $\mathrm{R}$. The historical trends of these variables are given at Figure 1. 


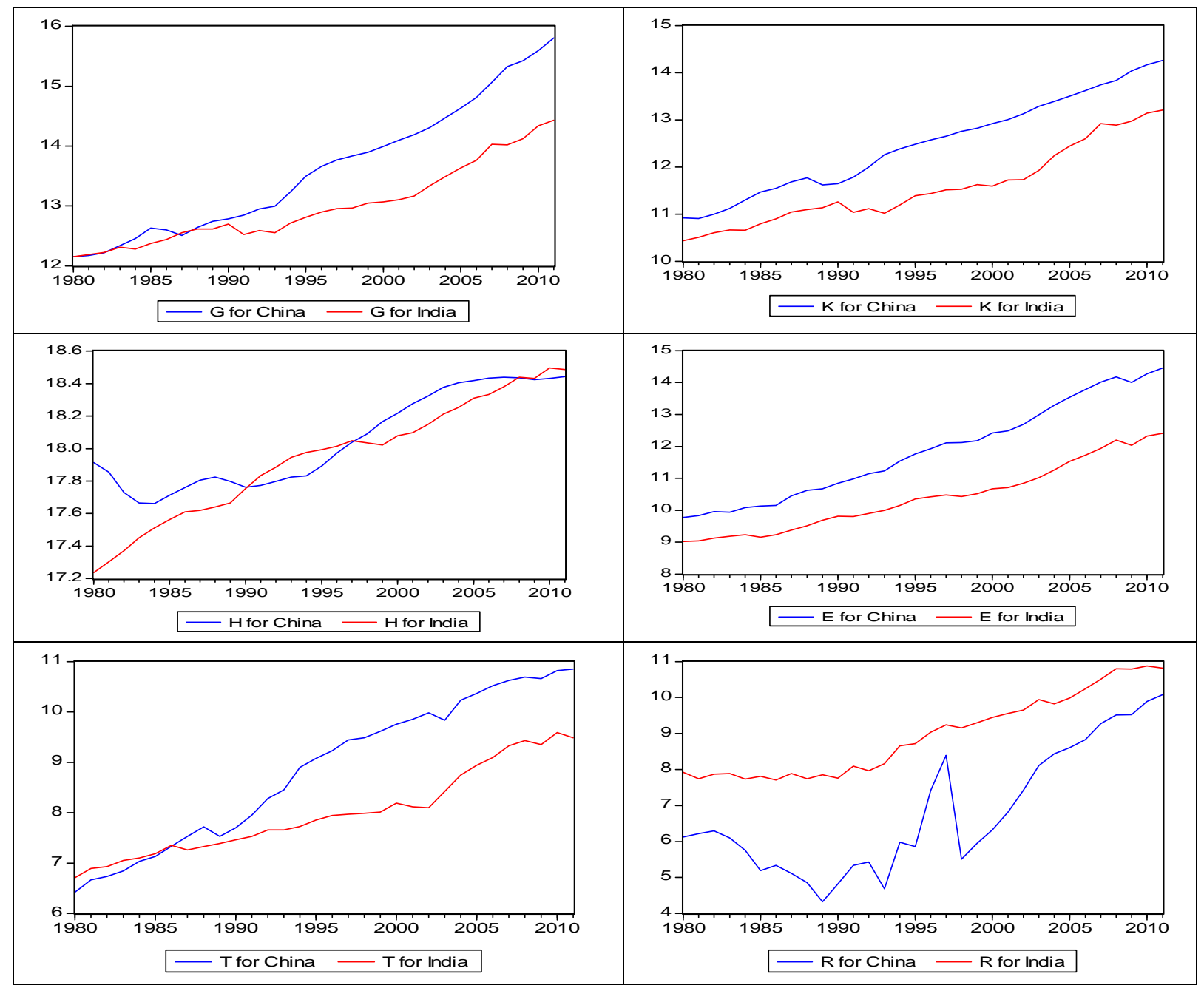

Figure 1: Historical trends for these variables

From this figure we found that for GDP series the trend of both countries showing upwards trend where GDP data for China growing up faster than India after 1988. The series for real gross capital formation showing upward trend for both countries. Total enrollments in secondary level of education indicate that the trend growing up after 1991 in case of China where as upward trend is observed in case of India. For traditional export series both countries showing upwards trend. We found from international tourism receipt series that starting from almost same point China's tourism receipt is growing up faster than India after 1986. The remittance series showing upwards trend in case of India but trends is not clear in case of China. The descriptive statistics of these variables are presented in Table- 1 . 
Table 1: Descriptive statistics for these series for China and India

\begin{tabular}{|l|l|l|l|l|l|l|l|l|l|}
\hline & Series & Mean & Median & Max. & Min. & $\begin{array}{l}\text { Std. } \\
\text { Dev }\end{array}$ & Skewness & Kurtosis & $\begin{array}{l}\text { P- } \\
\text { Value } \\
\text { (J-B) }\end{array}$ \\
\hline \multirow{5}{*}{ China } & G & 13.6150 & 13.5791 & 15.8059 & 12.1516 & 1.1050 & 0.4231 & 1.9962 & 0.6168 \\
\cline { 2 - 10 } & $\mathrm{K}$ & 12.4878 & 12.5289 & 14.2583 & 10.9095 & 1.0230 & 0.0876 & 1.8294 & 0.6929 \\
\cline { 2 - 11 } & $\mathrm{H}$ & 18.0468 & 17.9426 & 18.4434 & 17.6627 & 0.2896 & 0.2478 & 1.4027 & 0.5549 \\
\cline { 2 - 10 } & $\mathrm{E}$ & 11.8635 & 11.8430 & 14.4593 & 9.7787 & 1.5158 & 0.2327 & 1.7603 & 0.6107 \\
\cline { 2 - 10 } & $\mathrm{T}$ & 8.8531 & 9.1523 & 10.8525 & 6.4248 & 1.4530 & -0.1752 & 1.5986 & 0.5488 \\
\cline { 2 - 10 } & $\mathrm{R}$ & 6.7985 & 6.1715 & 10.0822 & 4.3307 & 1.7327 & 0.5196 & 1.9228 & 0.5245 \\
\hline India & $\mathrm{G}$ & 13.0012 & 12.8553 & 14.4296 & 12.1526 & 0.6608 & 0.7323 & 2.3377 & 0.5937 \\
\cline { 2 - 10 } & $\mathrm{K}$ & 11.5736 & 11.4105 & 13.2096 & 10.4335 & 0.8227 & 0.6493 & 2.2902 & 0.5321 \\
\cline { 2 - 10 } & $\mathrm{H}$ & 17.9420 & 18.0038 & 18.4947 & 17.2362 & 0.3631 & -0.2362 & 2.0409 & 0.7665 \\
\cline { 2 - 10 } & $\mathrm{E}$ & 10.4104 & 10.3878 & 12.4104 & 9.0243 & 1.0655 & 0.4336 & 2.0229 & 0.6205 \\
\cline { 2 - 10 } & $\mathrm{T}$ & 7.9945 & 7.9023 & 9.5937 & 6.7093 & 0.8485 & 0.5196 & 2.1369 & 0.5961 \\
\cline { 2 - 10 } & $\mathrm{R}$ & 8.9610 & 8.8823 & 10.8788 & 7.7128 & 1.1235 & 0.3712 & 1.7006 & 0.5246 \\
\hline
\end{tabular}

From Table-1, we found that the mean return of the G, K, H, E, T and R for China are 13.6150, $12.4878,18.0468,11.8635,8.8531$ and 6.7985 respectively and for India are 13.0012, 11.5736, $17.9420,10.4104,7.9945$ and 8.9610 respectively. The ranges of the standard deviation of these series for China are from 0.2896 to 1.7327 and for India are from 0.3631 to 1.1235 . Among these variables $\mathrm{H}$ present the smallest and R present the highest standard deviation in case of both countries. All of these series for both two countries are not normally distributed as their kurtoses are less than 3. From this table we also found that the series $\mathrm{T}$ in case of China and the series $\mathrm{H}$ in case of India are negatively skewed. In order to find out the causal relationship we will follow the following steps.

At the first step we need to confirm the existence of stationarity of these individual time series data. For this reason we used ADF test (Augmented Dickey-Fuller 1979) and PP test of Phillips and Perron (1988). The estimation results for unit root test are done for both intercept and intercept $\&$ trend. These results are reported at Table-2. From Table-2, we found that we can not reject the null hypothesis of nonstationarity for all of the series for their level which indicate that all of these series are non stationary both at 5\% and 10\% significance level for intercept and intercept \& trend for their level in case of China. Then we consider first difference and found that all of these series are stationary at $1 \%$ except the series $\mathrm{G}$ and $\mathrm{H}$, but these two series also get stationarity at $5 \%$ level of significance in case of China. The estimation results of Table 2 also indicate that all of the series fail to achieve stationarity at the level but these series obtain stationarity at their first difference at $5 \%$ as well as $1 \%$ significance level in case of India. So finally we found the stationarity of these series at their first difference for both countries. 
Table 2: Unit root test estimation results

\begin{tabular}{|c|c|c|c|c|c|c|c|c|c|}
\hline & & \multicolumn{4}{|c|}{ China } & \multicolumn{3}{c|}{ India } \\
\hline & & \multicolumn{2}{|c|}{ ADF } & \multicolumn{2}{c|}{ PP } & \multicolumn{2}{c|}{ ADF } & \multicolumn{2}{c|}{ PP } \\
\hline \multirow{2}{*}{ Variables } & & Inter. & $\begin{array}{c}\text { Inter. \& } \\
\text { Trend }\end{array}$ & Inter. & $\begin{array}{c}\text { Inter. \& } \\
\text { Trend }\end{array}$ & Inter. & $\begin{array}{c}\text { Inter. \& } \\
\text { Trend }\end{array}$ & $\begin{array}{c}\text { Inter. } \\
\text { Inter. \& } \\
\text { Trend }\end{array}$ \\
\hline \multirow{2}{*}{$\mathrm{G}$} & 0 & 3.0330 & -0.6627 & 3.1100 & -0.8211 & 2.2640 & -0.2706 & 2.4720 & -0.2706 \\
\cline { 2 - 10 } & 1 & $-3.290^{*}$ & $-3.944^{*}$ & $-3.2907^{*}$ & $-3.718^{*}$ & -5.0523 & -6.0639 & -5.1389 & -6.0638 \\
\hline \multirow{2}{*}{$\mathrm{K}$} & 0 & 1.0674 & -3.686 & 1.2319 & -2.6367 & 1.1462 & -0.8934 & 1.1210 & -0.9867 \\
\cline { 2 - 10 } & 1 & -3.883 & -4.620 & -3.786 & -3.6230 & -5.2327 & -5.5620 & -5.2978 & -5.5681 \\
\hline \multirow{2}{*}{$\mathrm{H}$} & 0 & -1.062 & -2.092 & -0.0180 & -1.6790 & -2.2615 & -2.3598 & -2.0373 & -2.4270 \\
\cline { 2 - 10 } & 1 & $-2.733^{* *}$ & $-4.094^{*}$ & $-3.146^{*}$ & $-4.1871^{*}$ & -4.0642 & -4.3518 & -4.0657 & -4.3830 \\
\hline \multirow{2}{*}{$\mathrm{E}$} & 0 & 1.1770 & -2.5608 & 1.1992 & -2.5620 & 1.6300 & -1.6166 & 1.7413 & -1.5986 \\
\cline { 2 - 10 } & 1 & -5.212 & -5.4040 & -5.2090 & -5.4042 & -5.2263 & -5.7826 & -5.2389 & -5.7265 \\
\hline \multirow{2}{*}{$\mathrm{T}$} & 0 & -1.2293 & -1.2271 & -1.2791 & -1.1880 & 0.2476 & -1.4410 & 0.2545 & -1.5829 \\
\cline { 2 - 10 } & 1 & -5.8511 & -5.9191 & -5.8470 & -5.9492 & -5.0309 & -5.0932 & -5.0382 & -5.0952 \\
\hline \multirow{2}{*}{$\mathrm{R}$} & 0 & -0.4547 & -2.3383 & -0.3371 & -2.1686 & 0.7683 & -2.7937 & 0.8270 & -2.7937 \\
\cline { 2 - 9 } & 1 & -6.1021 & -6.3300 & -6.2201 & -9.5614 & -6.4050 & -6.6983 & -6.3047 & -6.6764 \\
\hline
\end{tabular}

Note: $*$ indicate $5 \%$ and $* *$ indicate $10 \%$

At the second step we need to find out whether they are cointegrated or not. Johansen (1988) and Johansen and Juselius (1990) suggested two test procedures for cointegrating analysis which are Maximum Eigen value test and Trace test. Johansen's procedure of multivariate cointegration requires the existence of sufficient number of time lags. Akaike Information Criterion with critical values from Osterwald-Lenum (1992) indicates the lag length is 2. The estimated results of Maximum Eigen value test and Trace test for both countries are given at Table-3. The Maximum Eigen Value test statistic shows that the estimated test statistics both in trend and without trend are not less than the critical value for the null hypothesis $r=0$ which indicates the hypothesis of no cointegration is rejected in case of China. Then we consider the null hypothesis $r \leq 1$ and found that the estimated test statistic is less than the critical value which indicates that there is one cointegrating equation present in case of China. The estimated result of Trace test reported at the same table gives similar result. From this Table we also found the existence of one cointegrating equation in case of India based on both Maximum Eigen value test and Trace test. The existence of the cointegrating equations prompts us to confirm the long run equilibrium relationship among these variables for both countries. The long run parameter estimation results are given at Table-4.

Table 3: Cointegrating analysis for these variables

\begin{tabular}{|c|c|c|c|c|c|c|c|c|}
\hline \multirow{4}{*}{$\begin{array}{c}\text { Null } \\
\text { Hypothesis }\end{array}$} & \multicolumn{4}{|c|}{ China } & \multicolumn{4}{|c|}{ India } \\
\hline & \multicolumn{2}{|c|}{$\begin{array}{l}\text { Maximum Eigen } \\
\text { Value test }\end{array}$} & \multicolumn{2}{|c|}{ Trace test } & \multicolumn{2}{|c|}{$\begin{array}{c}\text { Maximum Eigen } \\
\text { Value test }\end{array}$} & \multicolumn{2}{|c|}{ Trace test } \\
\hline & $\begin{array}{l}\text { Without } \\
\text { trend }\end{array}$ & $\begin{array}{l}\text { With } \\
\text { trend }\end{array}$ & $\begin{array}{c}\text { Without } \\
\text { trend }\end{array}$ & $\begin{array}{l}\text { With } \\
\text { trend }\end{array}$ & $\begin{array}{l}\text { Without } \\
\text { trend }\end{array}$ & $\begin{array}{l}\text { With } \\
\text { trend }\end{array}$ & $\begin{array}{l}\text { Without } \\
\text { trend }\end{array}$ & $\begin{array}{l}\text { With } \\
\text { trend }\end{array}$ \\
\hline & $\begin{array}{c}\text { Test } \\
\text { Statistics } \\
\text { (Critical } \\
\text { Value) }\end{array}$ & $\begin{array}{c}\text { Test } \\
\text { Statistics } \\
\text { (Critical } \\
\text { Value) }\end{array}$ & $\begin{array}{c}\text { Test } \\
\text { Statistics } \\
\text { (Critical } \\
\text { Value) }\end{array}$ & $\begin{array}{c}\text { Test } \\
\text { Statistics } \\
\text { (Critical } \\
\text { Value) }\end{array}$ & $\begin{array}{c}\text { Test } \\
\text { Statistics } \\
\text { (Critical } \\
\text { Value) }\end{array}$ & $\begin{array}{c}\text { Test } \\
\text { Statistics } \\
\text { (Critical } \\
\text { Value) }\end{array}$ & $\begin{array}{c}\text { Test } \\
\text { Statistics } \\
\text { (Critical } \\
\text { Value) }\end{array}$ & $\begin{array}{c}\text { Test } \\
\text { Statistics } \\
\text { (Critical } \\
\text { Value) }\end{array}$ \\
\hline$r=0$ & $\begin{array}{l}48.6044 \\
(36.630)\end{array}$ & $\begin{array}{l}47.4472 \\
(43.419)\end{array}$ & $\begin{array}{l}116.810 \\
(83.937)\end{array}$ & $\begin{array}{l}123.602 \\
(107.34)\end{array}$ & $\begin{array}{l}45.5988 \\
(36.630)\end{array}$ & $\begin{array}{l}56.5564 \\
(43.415)\end{array}$ & $\begin{array}{l}110.396 \\
(83.937)\end{array}$ & $\begin{array}{l}137.206 \\
(107.34)\end{array}$ \\
\hline$r \leq 1$ & $\begin{array}{l}29.2701 \\
(30.439)\end{array}$ & $\begin{array}{l}26.7218 \\
(37.163)\end{array}$ & $\begin{array}{l}58.1211 \\
(60.061)\end{array}$ & $\begin{array}{l}76.1552 \\
(79.341)\end{array}$ & $\begin{array}{l}28.1859 \\
(30.439)\end{array}$ & $\begin{array}{l}27.1873 \\
(37.163)\end{array}$ & $\begin{array}{l}54.7975 \\
(60.061)\end{array}$ & $\begin{array}{l}74.6499 \\
(79.341)\end{array}$ \\
\hline
\end{tabular}


Table 4: long run parameter estimation result

\begin{tabular}{|c|c|c|c|c|c|c|c|c|}
\hline & $\begin{array}{c}\text { Explanatory } \\
\text { Variable }\end{array}$ & $\mathrm{G}$ & $\mathrm{K}$ & $\mathrm{H}$ & $\mathrm{E}$ & $\mathrm{T}$ & $\mathrm{R}$ & $\begin{array}{c}\text { Log- } \\
\text { likelihood }\end{array}$ \\
\hline \multirow{2}{*}{ China } & Coefficient & -1 & 0.8582 & -0.0397 & 0.3415 & 0.2669 & 0.0660 & \multirow{2}{*}{28.569} \\
\cline { 2 - 10 } & t-statistics & - & 4.336 & -0.179 & 2.443 & 2.709 & 2.344 & \\
\hline \multirow{2}{*}{ India } & Coefficient & -1 & 0.7971 & -0.1136 & 0.0676 & 0.1093 & 0.0589 & \multirow{2}{*}{61.324} \\
\cline { 2 - 9 } & t-statistics & - & 9.880 & -1.212 & 2.780 & 1.129 & 1.991 & \\
\hline
\end{tabular}

From Table 4, we found that in the long run traditional export, tourism and remittance have significant positive effect on the GDP of China and traditional export and remittance have positive significant effect on the GDP of India whereas tourism has positive effect on the GDP of India but it is statistically insignificant. According to Engle and Granger (1987), if there is a cointegration relationship among some variables then there exists long run as well as corresponding short run relationship among these variable.

The ECM has several advantages such as it incorporates both short and long run effect and it also present the stationarity which indicate that the standard regression techniques are valid (Harris, 1995). ECM estimation results are given at Table-5. From this table we found that traditional exports, tourism receipt and remittance are statistically significant and other capitals also have significant effect on the growth model except some of capital at their different lag values. It also showed that the error correction term of GDP, traditional exports and tourism are significant in case of China and GDP, traditional export and remittance are significant in case of India. 
Table 5: ECM estimation results

\begin{tabular}{|c|c|c|c|c|c|c|c|c|}
\hline & \multicolumn{4}{|l|}{ China } & \multicolumn{4}{|l|}{ India } \\
\hline & $\mathrm{G}$ & $E$ & $\mathrm{~T}$ & $\mathrm{R}$ & $\mathrm{G}$ & $E$ & $\mathrm{~T}$ & $\mathrm{R}$ \\
\hline Constant & $\begin{array}{l}0.1652 \\
(2.194) \\
\end{array}$ & $\begin{array}{l}0.3634 \\
(2.943)\end{array}$ & $\begin{array}{l}0.0127 \\
(0.074)\end{array}$ & $\begin{array}{l}-0.6709 \\
(-0.610)\end{array}$ & $\begin{array}{l}0.0430 \\
(0.938)\end{array}$ & $\begin{array}{l}0.1125 \\
(2.012)\end{array}$ & $\begin{array}{l}0.0502 \\
(0.766)\end{array}$ & $\begin{array}{l}0.2017 \\
(3.198)\end{array}$ \\
\hline $\mathrm{EC}$ & $\begin{array}{l}-0.8964 \\
(-3.101)\end{array}$ & $\begin{array}{l}-1.3003 \\
(-2.742)\end{array}$ & $\begin{array}{l}0.1622 \\
(2.247)\end{array}$ & $\begin{array}{l}-0.2867 \\
(-0.067)\end{array}$ & $\begin{array}{l}-0.7671 \\
(-1.190)\end{array}$ & $\begin{array}{l}-0.7732 \\
(-1.983)\end{array}$ & $\begin{array}{l}-0.9106 \\
(-0.987)\end{array}$ & $\begin{array}{l}-5.159 \\
(-5.814)\end{array}$ \\
\hline$\Delta \mathrm{G}$ & $\begin{array}{l}0.5671 \\
(2.487) \\
\end{array}$ & $\begin{array}{l}-0.2410 \\
(-1.206)\end{array}$ & $\begin{array}{l}0.4470 \\
(1.750)\end{array}$ & $\begin{array}{l}-0.7748 \\
(-2.318) \\
\end{array}$ & $\begin{array}{l}0.5671 \\
(2.014)\end{array}$ & $\begin{array}{l}0.4178 \\
(0.498) \\
\end{array}$ & $\begin{array}{l}-0.8124 \\
(-0.221) \\
\end{array}$ & $\begin{array}{l}1.4110 \\
(1.991)\end{array}$ \\
\hline$\Delta \mathrm{G}(-1)$ & $\begin{array}{l}0.8737 \\
(2.840) \\
\end{array}$ & $\begin{array}{l}-0.1042 \\
(-0.206) \\
\end{array}$ & $\begin{array}{l}-1.4473 \\
(-2.075) \\
\end{array}$ & $\begin{array}{l}0.5771 \\
(0.128) \\
\end{array}$ & $\begin{array}{l}1.2289 \\
(1.951) \\
\end{array}$ & $\begin{array}{l}0.8877 \\
(1.155) \\
\end{array}$ & $\begin{array}{l}0.0192 \\
(0.021) \\
\end{array}$ & $\begin{array}{l}2.5866 \\
(2.984) \\
\end{array}$ \\
\hline$\Delta \mathrm{G}(-2)$ & $\begin{array}{l}0.0478 \\
(0.245) \\
\end{array}$ & $\begin{array}{l}0.3180 \\
(0.995)\end{array}$ & $\begin{array}{l}0.6788 \\
(1.537)\end{array}$ & $\begin{array}{l}3.3760 \\
(1.186)\end{array}$ & $\begin{array}{l}1.0715 \\
(1.612)\end{array}$ & $\begin{array}{l}-0.1318 \\
(-0.162)\end{array}$ & $\begin{array}{l}-0.2280 \\
(-0.239)\end{array}$ & $\begin{array}{l}0.9680 \\
(1.058)\end{array}$ \\
\hline$\Delta K$ & $\begin{array}{l}-1.2410 \\
(-0.222) \\
\end{array}$ & $\begin{array}{l}0.9145 \\
(0.784) \\
\end{array}$ & $\begin{array}{l}1.112 \\
(1.415) \\
\end{array}$ & $\begin{array}{l}0.4651 \\
(1.089) \\
\end{array}$ & $\begin{array}{l}0.4782 \\
(1.247) \\
\end{array}$ & $\begin{array}{l}-0.3514 \\
(-0.345) \\
\end{array}$ & $\begin{array}{l}0.8412 \\
(0.558) \\
\end{array}$ & $\begin{array}{l}1.4740 \\
(2.013) \\
\end{array}$ \\
\hline$\Delta \mathrm{K}(-1)$ & $\begin{array}{l}-0.0445 \\
(-0.150) \\
\end{array}$ & $\begin{array}{l}-0.7632 \\
(-1.569) \\
\end{array}$ & $\begin{array}{l}0.4266 \\
(0.635)\end{array}$ & $\begin{array}{l}2.1858 \\
(4.326) \\
\end{array}$ & $\begin{array}{l}-0.6998 \\
(-1.599) \\
\end{array}$ & $\begin{array}{l}-0.0525 \\
(-0.098) \\
\end{array}$ & $\begin{array}{l}0.6468 \\
(1.033)\end{array}$ & $\begin{array}{l}-0.3785 \\
(-0.628)\end{array}$ \\
\hline$\Delta \mathrm{K}(-2)$ & $\begin{array}{l}-0.1997 \\
(-0.821) \\
\end{array}$ & $\begin{array}{l}0.3532 \\
(0.885) \\
\end{array}$ & $\begin{array}{l}0.4224 \\
(0.766) \\
\end{array}$ & $\begin{array}{l}-2.0171 \\
(-3.552) \\
\end{array}$ & $\begin{array}{l}-0.3038 \\
(-0.717) \\
\end{array}$ & $\begin{array}{l}0.0691 \\
(0.133) \\
\end{array}$ & $\begin{array}{l}0.3670 \\
(0.605) \\
\end{array}$ & $\begin{array}{c}-0.0667 \\
(-0.114) \\
\end{array}$ \\
\hline$\Delta \mathrm{H}$ & $\begin{array}{l}0.7920 \\
(0.215) \\
\end{array}$ & $\begin{array}{l}0.4785 \\
(1.892) \\
\end{array}$ & $\begin{array}{l}1.0270 \\
(0.578) \\
\end{array}$ & $\begin{array}{l}0.2245 \\
(0.248) \\
\end{array}$ & $\begin{array}{l}-0.6847 \\
(-1.128) \\
\end{array}$ & $\begin{array}{l}0.4622 \\
(1.021) \\
\end{array}$ & $\begin{array}{l}0.3574 \\
(1.245)\end{array}$ & $\begin{array}{l}1.2301 \\
(0.087) \\
\end{array}$ \\
\hline$\Delta \mathrm{H}(-1)$ & $\begin{array}{l}0.5252 \\
(0.819)\end{array}$ & $\begin{array}{l}2.2808 \\
(2.170)\end{array}$ & $\begin{array}{l}0.5839 \\
(0.401)\end{array}$ & $\begin{array}{l}1.9679 \\
(0.210)\end{array}$ & $\begin{array}{l}-1.7392 \\
(-2.085)\end{array}$ & $\begin{array}{l}-1.9585 \\
(-1.962)\end{array}$ & $\begin{array}{l}-0.5825 \\
(-0.488) \\
\end{array}$ & $\begin{array}{l}2.1850 \\
(1.903) \\
\end{array}$ \\
\hline$\Delta \mathrm{H}(-2)$ & $\begin{array}{l}-0.5244 \\
(-0.960) \\
\end{array}$ & $\begin{array}{l}-1.5884 \\
(-1.773) \\
\end{array}$ & $\begin{array}{l}-1.7886 \\
(-1.445) \\
\end{array}$ & $\begin{array}{l}-1.4800 \\
(-0.185) \\
\end{array}$ & $\begin{array}{l}2.1517 \\
(2.629) \\
\end{array}$ & $\begin{array}{l}1.4147 \\
(1.519) \\
\end{array}$ & $\begin{array}{l}1.7325 \\
(1.479) \\
\end{array}$ & $\begin{array}{c}-1.4171 \\
(-1.258) \\
\end{array}$ \\
\hline$\Delta \mathrm{E}$ & $\begin{array}{l}0.9415 \\
(0.985) \\
\end{array}$ & $\begin{array}{l}1.1450 \\
(2.135) \\
\end{array}$ & $\begin{array}{l}0.4578 \\
(1.678) \\
\end{array}$ & $\begin{array}{l}0.7283 \\
(0.478) \\
\end{array}$ & $\begin{array}{l}1.4570 \\
(1.973) \\
\end{array}$ & $\begin{array}{l}0.7884 \\
(2.012) \\
\end{array}$ & $\begin{array}{l}0.5547 \\
(0.112) \\
\end{array}$ & $\begin{array}{l}-1.2240 \\
(-2.354) \\
\end{array}$ \\
\hline$\Delta \mathrm{E}(-1)$ & $\begin{array}{l}-0.4565 \\
(-1.471) \\
\end{array}$ & $\begin{array}{l}-0.9348 \\
(-1.837) \\
\end{array}$ & $\begin{array}{l}0.6304 \\
(0.896) \\
\end{array}$ & $\begin{array}{l}2.3012 \\
(0.507) \\
\end{array}$ & $\begin{array}{l}-0.0620 \\
(-0.246) \\
\end{array}$ & $\begin{array}{l}-0.0399 \\
(-0.130) \\
\end{array}$ & $\begin{array}{l}-0.1956 \\
(-0.543) \\
\end{array}$ & $\begin{array}{l}-0.2823 \\
(-0.816) \\
\end{array}$ \\
\hline$\Delta \mathrm{E}(-2)$ & $\begin{array}{l}-0.6554 \\
(-2.389)\end{array}$ & $\begin{array}{l}-0.639 \\
(-1.420)\end{array}$ & $\begin{array}{l}0.6169 \\
(0.992)\end{array}$ & $\begin{array}{l}1.2085 \\
(0.301) \\
\end{array}$ & $\begin{array}{l}-0.0198 \\
(-0.094)\end{array}$ & $\begin{array}{l}.03851 \\
(1.536)\end{array}$ & $\begin{array}{l}0.5918 \\
(2.013)\end{array}$ & $\begin{array}{l}0.2081 \\
(0.735)\end{array}$ \\
\hline$\Delta \mathrm{T}$ & $\begin{array}{l}0.4861 \\
(0.885) \\
\end{array}$ & $\begin{array}{l}0.6784 \\
(1.874)\end{array}$ & $\begin{array}{l}1.4457 \\
(2.413)\end{array}$ & $\begin{array}{l}0.6691 \\
(0.457) \\
\end{array}$ & $\begin{array}{l}0.6822 \\
(0.257)\end{array}$ & $\begin{array}{l}0.7852 \\
(0.614)\end{array}$ & $\begin{array}{l}-1.3520 \\
(-2.113)\end{array}$ & $\begin{array}{l}0.5783 \\
(0.789)\end{array}$ \\
\hline$\Delta \mathrm{T}(-1)$ & $\begin{array}{l}0.1320 \\
(0.957) \\
\end{array}$ & $\begin{array}{l}0.1800 \\
(0.795) \\
\end{array}$ & $\begin{array}{l}-0.2362 \\
(-0.755) \\
\end{array}$ & $\begin{array}{l}-1.339 \\
(-0.665) \\
\end{array}$ & $\begin{array}{l}0.0547 \\
(0.218) \\
\end{array}$ & $\begin{array}{l}0.2570 \\
(0.841) \\
\end{array}$ & $\begin{array}{l}-0.0110 \\
(-0.030) \\
\end{array}$ & $\begin{array}{l}-1.1568 \\
(-3.354) \\
\end{array}$ \\
\hline$\Delta \mathrm{T}(-2)$ & $\begin{array}{l}0.1568 \\
(1.357) \\
\end{array}$ & $\begin{array}{l}0.5001 \\
(0.264) \\
\end{array}$ & $\begin{array}{l}0.0116 \\
(0.044) \\
\end{array}$ & $\begin{array}{l}0.5238 \\
(0.310) \\
\end{array}$ & $\begin{array}{l}-0.2178 \\
(-0.708) \\
\end{array}$ & $\begin{array}{l}-0.5282 \\
(-1.407) \\
\end{array}$ & $\begin{array}{l}-0.9510 \\
(-2.160) \\
\end{array}$ & $\begin{array}{c}-0.9492 \\
(-2.242) \\
\end{array}$ \\
\hline$\Delta \mathrm{R}$ & $\begin{array}{l}0.4478 \\
(0.571) \\
\end{array}$ & $\begin{array}{l}-0.4532 \\
(-0.314) \\
\end{array}$ & $\begin{array}{l}0.4879 \\
(0.848) \\
\end{array}$ & $\begin{array}{l}-2.487 \\
(-2.112) \\
\end{array}$ & $\begin{array}{l}0.8761 \\
(0.278) \\
\end{array}$ & $\begin{array}{l}0.2243 \\
(0.446)\end{array}$ & $\begin{array}{l}-0.4781 \\
(-0.879) \\
\end{array}$ & $\begin{array}{l}-1.2458 \\
(1.995)\end{array}$ \\
\hline$\Delta R(-1)$ & $\begin{array}{l}-0.0111 \\
(-0.585) \\
\end{array}$ & $\begin{array}{l}0.0169 \\
(0.543)\end{array}$ & $\begin{array}{l}0.0048 \\
(0.112)\end{array}$ & $\begin{array}{l}-0.3307 \\
(-1.189) \\
\end{array}$ & $\begin{array}{l}-0.0919 \\
(-0.664)\end{array}$ & $\begin{array}{l}-0.1230 \\
(-0.747) \\
\end{array}$ & $\begin{array}{l}-0.0328 \\
(-0.165) \\
\end{array}$ & $\begin{array}{l}-0.869 \\
(-4.561)\end{array}$ \\
\hline$\Delta \mathrm{R}(-2)$ & $\begin{array}{l}0.0020 \\
(0.099) \\
\end{array}$ & $\begin{array}{l}-0.0034 \\
(-0.102) \\
\end{array}$ & $\begin{array}{l}-0.0449 \\
(-0.956) \\
\end{array}$ & $\begin{array}{l}-0.513 \\
(-1.697) \\
\end{array}$ & $\begin{array}{l}-0.2441 \\
(-1.656) \\
\end{array}$ & $\begin{array}{l}-0.3359 \\
(-1.858) \\
\end{array}$ & $\begin{array}{l}-0.3477 \\
(-1.648) \\
\end{array}$ & $\begin{array}{l}-0.5005 \\
(-2.466) \\
\end{array}$ \\
\hline
\end{tabular}

Note: ( ) contains the t-statistic

Finally, in order to find out causal relationship among GDP, traditional exports, tourism receipt and remittance for China and India we used VAR Granger Causality/Block Exogeneity Wald Test. Under this system, an endogenous variable can be treated as exogenous. We used Chi-square (Wald) test statistic. The estimated results are given at Table-6. From this table we found that all the variables together are the granger cause of the GDP of China where none of the variable individually influences the GDP except the variables $\mathrm{K}$ and $\mathrm{H}$. For the regression equation traditional export, GDP are the influencing factor. Rest of the regression equation $\mathrm{T}$ and $\mathrm{R}$ indicate that none of the variables together and individually influence each other to grow up in case of China.

In case of India the estimated result for R equation indicate that GDP and traditional exports are the granger cause to the remittance of India and it also indicate that all of the variables together influence 
the remittance. Therefore, we found the evidence for unidirectional causality from traditional export to GDP in case of China and from remittance to GDP and traditional export in case of India.

Table 6: Block Exogeneity Wald Tests (Chi-square (Wald) test statistics)

\begin{tabular}{|c|c|c|c|c|c|c|c|}
\hline & & \multicolumn{3}{|c|}{ China } & \multicolumn{3}{|c|}{ India } \\
\hline $\begin{array}{c}\text { Dependent } \\
\text { Variable }\end{array}$ & Excluded & $\chi^{2}$ statistics & $\mathrm{DF}$ & $\mathrm{P}$ value & $\chi^{2}$ statistics & $\mathrm{DF}$ & $\mathrm{P}$ value \\
\hline \multirow[t]{6}{*}{$G$} & $\mathrm{~K}$ & 9.354516 & 2 & 0.0093 & 0.717704 & 2 & 0.6985 \\
\hline & $\mathrm{H}$ & 8.334309 & 2 & 0.0155 & 0.998049 & 2 & 0.6071 \\
\hline & $\mathrm{E}$ & 1.044668 & 2 & 0.5931 & 0.370066 & 2 & 0.8311 \\
\hline & $\mathrm{T}$ & 0.439331 & 2 & 0.8028 & 3.547639 & 2 & 0.1697 \\
\hline & $\mathrm{R}$ & 0.611880 & 2 & 0.7364 & 0.771165 & 2 & 0.6801 \\
\hline & All & 26.61959 & 10 & 0.0030 & 7.092623 & 10 & 0.7167 \\
\hline \multirow[t]{6}{*}{$E$} & $\mathrm{G}$ & 5.035502 & 2 & 0.0806 & 0.476140 & 2 & 0.7881 \\
\hline & $\mathrm{K}$ & 8.306082 & 2 & 0.0157 & 0.409840 & 2 & 0.8147 \\
\hline & $\mathrm{H}$ & 1.250263 & 2 & 0.5352 & 2.554413 & 2 & 0.2788 \\
\hline & $\mathrm{T}$ & 1.694439 & 2 & 0.4286 & 1.468275 & 2 & 0.4799 \\
\hline & $\mathrm{R}$ & 3.657537 & 2 & 0.1606 & 0.206189 & 2 & 0.9020 \\
\hline & All & 18.58772 & 10 & 0.0458 & 10.48578 & 10 & 0.3990 \\
\hline \multirow[t]{6}{*}{$\mathrm{T}$} & $\mathrm{G}$ & 2.686443 & 2 & 0.2610 & 1.469738 & 2 & 0.4796 \\
\hline & $\mathrm{K}$ & 2.118560 & 2 & 0.3467 & 3.351584 & 2 & 0.1872 \\
\hline & $\mathrm{H}$ & 1.997393 & 2 & 0.3684 & 0.336918 & 2 & 0.8450 \\
\hline & $\mathrm{E}$ & 3.161661 & 2 & 0.2058 & 2.599393 & 2 & 0.2726 \\
\hline & $\mathrm{R}$ & 1.021067 & 2 & 0.6002 & 1.445067 & 2 & 0.4855 \\
\hline & All & 11.22839 & 10 & 0.3400 & 10.14367 & 10 & 0.4280 \\
\hline \multirow[t]{6}{*}{$\mathrm{R}$} & $\mathrm{G}$ & 1.831028 & 2 & 0.4003 & 5.108213 & 2 & 0.0778 \\
\hline & $\mathrm{K}$ & 1.082185 & 2 & 0.5821 & 1.908125 & 2 & 0.3852 \\
\hline & $\mathrm{H}$ & 2.414637 & 2 & 0.2990 & 0.186130 & 2 & 0.9111 \\
\hline & $\mathrm{E}$ & 0.048724 & 2 & 0.9759 & 5.732669 & 2 & 0.0569 \\
\hline & $\mathrm{T}$ & 0.526139 & 2 & 0.7687 & 0.950001 & 2 & 0.6219 \\
\hline & All & 12.08727 & 10 & 0.2793 & 24.36666 & 10 & 0.0067 \\
\hline
\end{tabular}

\section{Conclusions}

This paper empirically examines the role of disaggregating exports into traditional export, international tourism receipt and foreign remittance in case of China and India and secondly, the causality among these disaggregating variables is examined. The empirical analysis considers the data from the period 1980-2011. In the long run traditional export, tourism and remittance have significant positive effect on the GDP of China and traditional export and remittance have positive significant effect on the GDP of India whereas tourism has positive effect on the GDP of India which is statistically insignificant. The error correction in term of GDP, traditional exports are significant in case of China and GDP, traditional export and remittance are significant in case of India. Finally, we found the evidence for unidirectional causality from traditional export to GDP in case of China and from remittance to GDP and traditional export in case of India. 
Therefore, traditional export, tourism and foreign remittance are the important factors for these two BCIM countries. So, Government of the both countries should adapt new policy to give flexible condition for tourism and encourages more people to go to aboard to earn more remittance. In our study we only consider two BCIM countries such as China and India and more researchers are necessary for establishing generalized results.

\section{References}

Agosin, M. (1999). Trade and growth in Chile. Cepal Review 68, pp.79-100

Balaguer, J., Cantavella-Jordá, M. (2004). Export Composition and Spanish Economic Growth: Evidence from the 20th Century. Journal of Policy Planning 26, pp.165-179

Barro, R. J., Sala-i-Martin, X. (1995). Economic growth. McGraw-Hill, New York.

Boriss, S., Herzer, D. (2006). Export-Led Growth hypothesis: evidence for Chile. Applied Economics Letters 13, pp. 319-324.

Cortés-Jiménez, I. M., Pulina, C. P., and Artis,M.(2009). Tourism and exports as a means of growth. Research Institute of Applied Economics, Working Papers, pp.1-28.

Chang, T. and Caudill, S.B. (2005). Financial development and economic growth: the case of Taiwan. Applied Economics, 37, 1329-1335.

Crespo-Cuaresma, J. and Wörz, J. (2003). On Exports Composition and Growth. Review of World Economics 141, pp.33-49.

Dickey, D. A. and Fuller, W.A. (1979). Distribution of the estimators for auto-regressive time series with a unit root. Journal of the American Statistical Association, 74, pp. 427- 431.

Durbarry, R. (2004). Tourism and Economic Growth: The Case of Mauritius. Tourism Economics 10, pp.389-401.

Engle, R.F., Granger, C.W.J. (1987). Cointegration and Error Correction: Representation, Estimation and Testing. Econometrica 55, pp.251-276.

Fosu, A.K. (1990). Export Composition and the Impact of Exports on Economic Growth of Developing Economies. Economics Letters 34, pp.67-71.

Granger, C.W.J. (1969). Investigating Causal Relations by Econometric Models and Cross Spectral Methods. Econometrica 37.

Greenaway, D., Morgan, W. and Wright, P. (1999). Exports, Export Composition and Growth. Journal of International Trade and Economic Development 8, pp.41-51.

Grossman, G.M. and Helpman, E. (1991). Innovation and growth in the global economy. MIT Press, Cambridge. 
Harris, R. (1995). Cointegration Analysis in Econometric Modelling. Prentice Hall/Harverster Wheatsheaf.

Helpman, E. and Krugman, P. (1985). Market Structure and International Trade. MIT Press.

Hendry, D. F. (1979). Productive Failure Econometric Modelling in Macroeconomics: The Transmission Demand for Money, in Economic Modeling: Current Issues and Problems in Macroeconomic Modeling in the UK and the USA, (ed.), London: P. Ormerod.

Hendry, D.F. (1995). Dynamic Econometrics, London: Oxford University Press, pp. 577-629

IMF, International Financial Statistics, 1997

Johansen, S. (1988). Statistical Analysis of Cointegrating Vectors. Journal of Economic Dynamics and Control 12, pp.231-254.

Johansen, S. and Juselius, K. (1990). Maximum likelihood estimation and inference on cointegration with application to the demand for money. Oxford Bulletin of Economics and Statistics, 52, pp. 169-210.

Kalirajan, K. and Singh, K. (2008). A Comparative Analysis of China's Recent Export Performances. Asian Economic Papers, Winter 2008, Vol.1, No.7, 1-28.

Krueger, A. (1980). Trade policy as an input to development. American Economic Review 70, pp.188292.

Lanza, A., Temple, P. and Urga, G. (2003). The implications of tourism specialization in the long run: An econometric analysis for 13 OECD economies. Tourism Management, 24, 315-321.

Lee, C. C. and Chen, M. S. (2008). Structure breaks, tourism development, and economic growth: Evidence from Taiwan. Mathematics and Computers in Simulation, 77, 358-368.

Mankiw, N.G. (2004). Principles of economics, Thomson - South-Western, USA.

McKinnon, R. (1964). Foreign exchange constraint in economic development and efficient aid allocation. Economic Journal 74, pp.388-409.

Osterwald-Lenum, M.(1992). Practioners corner a note with quartiles of the asymptotic distribution of the maximum likelihood cointegration rank test statistics. Oxford Bulletin of Economics and Statistics, $54,461-472$.

Phillips, P.C.B. Perron, P. (1988). Testing for unit roots in time series regression, Biometrika 75 pp. 335-346.

Rahman, M.M., Shao, Y.H. and Zhu, J.P. (2010). Contribution of International Flow of Capital and Product Services on the GDP of Maldides. Pakistan Journal of Social Sciences 7(6): 408-414. 
Ruiz, R.T. and Corrons, A.L. (2010). EU-Mediterranen Migration and Remittance Flows: A tool for Co-Development and Leveraging Foreign Investment.

Silva-Ruete, J. (2006). The Development of China's Export Performance, Conference presented at the Central Reserve Bank of Peru, Lima, Peru, March 7, 2006.

Sinclair, M.T. (1998). Tourism and Economic Development: A Survey. The Journal of Development Studies 34, pp.1-51.

Tong, S. Y. (2007). Comparing Trade Performance of China and India. East Asian Policy, 60-73

Wadhva, C.D. (1998). India's Export Performance and Policies: An Appraisal, Vikalpa, Vol.23, No.1, pp:61-74.

World Tourism Organization. (2004). Facts and Figures. Retrieved from http://www.worldtourism.org/market_research/facts/menu.html

Wu, J. L. (2003). Economic Reform in Contemporary China. Shanghai: Shanghai Far East Press.

Yang, Y. (2006). Empirical Analysis on the Relationship between Tourism and Economic Growth in China. Journal of Jiangxi University of Finance and Economics. 2, 101-106. 